\title{
PERAN MOTIVASI BERPRESTASI DAN STATUS SOSIAL EKONOMI TERHADAP MINAT MELANJUTKAN STUDI KE PERGURUAN TINGGI PADA SISWA PEREMPUAN DI TABANAN
}

\author{
Ni Putu Devi Merta Nadi ${ }^{1}$ dan Ni Made Yanthi Ary Agustini² \\ Email: devimertanadi@gmail.com ${ }^{1}$ \\ Universitas Udayana ${ }^{1,2}$
}

\begin{abstract}
Abstrak
Masa remaja merupakan periode transisi perkembangan dari masa kanak-kanak menuju masa dewasa. Pada periode ini, remaja cenderung mengalami kecemasan dan kebimbangan dalam menentukan perguruan tinggi, sehingga remaja perlu memperhatikan dan mengenali minatnya masing-masing. Terdapat beberapa hal yang mempengaruhi remaja dalam mengenali minat seperti status sosial ekonomi dan motivasi berprestasi. Adanya motivasi berprestasi serta status ekonomi yang baik akan menunjang minat remaja dalam meningkatkan minat melanjutkan studi ke perguruan tinggi. Namun realitanya status sosial ekonomi orangtua yang dimiliki siswa cenderung rendah. Sehingga, remaja berniat mengurungkan minatnya untuk melanjutkan studi ke perguruan tinggi. Penelitian ini menggunakan metode kuantitatif yang bertujuan untuk mengetahui peran motivasi berprestasi dan status sosial ekonomi terhadap minat melanjutkan studi ke perguruan tinggi pada siswa perempuan di Tabanan. Subjek dalam penelitian ini adalah 127 siswa perempuan SMA Negeri Kabupaten Tabanan dengan usia 17-18 tahun. Teknik analisis data yang digunakan dalam penelitian ini adalah regresi berganda. Hasil uji regresi berganda menunjukkan bahwa koefisien regresi sebesar 0,612 dan nilai koefisien determinasi sebesar 0,375 dengan nilai signifikansi sebesar $0,000(\mathrm{p}<0,05)$. Nilai koefisien beta terstandarisasi pada variabel motivasi berprestasi sebesar 0,062 dan variabel status sosial ekonomi sebesar -0,050. Hasil analisis data tersebut menunjukkan bahwa motivasi berprestasi dan status sosial ekonomi secara bersama-sama berperan meningkatkan minat melanjutkan studi ke perguruan tinggi pada siswa perempuan di Tabanan.
\end{abstract}

Kata kunci: Motivasi Berprestasi, Status Sosial Ekonomi, Minat Melanjutkan Studi Ke Perguruan Tinggi, Remaja

\section{PENDAHULUAN}

Masa remaja merupakan suatu periode transisi perkembangan dari masa kanak-kanak menuju masa dewasa. Perubahan yang terjadi meliputi perubahan secara biologis, kognitif, dan sosioemosional. Perubahan secara sosioemosional melibatkan adanya perubahan dalam hal emosi, kepribadian, relasi dengan teman sebaya dan konteks sosial. Relasi pada teman sebaya akan meningkatkan minat untuk bersaing terutama dalam hal pendidikan seperti prestasi baik dalam bidang akademik maupun non akademik, sehingga hal tersebut akan membuat remaja tidak realistis dalam menetapkan cita-cita (Santrock, 2007). Remaja dikatakan memandang dirinya sendiri sebagai diri orang lain, dan cenderung menetapkan cita-cita yang kurang realistis (Hurlock, 1996).

$$
\text { Menurut Santrock }
$$
pandangan sebagai diri orang lain yang dikembangkan oleh remaja, menyebabkan kesenjangan antara konsep diri ideal vs diri riil. Konsep diri ideal mendorong remaja menyesuaikan hal-hal yang diinginkan dengan konsep diri yang 
dimiliki, seperti menjadi individu yang positif di masa depan, ingin memasuki kampus yang baik, dan memiliki karir yang berhasil. Namun realitanya, siswa cenderung kesulitan dalam menentukan karir yang sesuai dengan minat mereka dan cenderung melakukan bimbingan karir dari orang lain (Sari \& Ratnaningsih, 2016). Kesulitan remaja dalam menentukan karir biasanya terjadi pada jenjang Sekolah Menengah Atas (SMA), karena pada jenjang tersebut siswa sudah mulai mempertimbangkan beberapa faktor dalam memilih karir seperti penampilan fisik, kondisi ekonomi keluarga, dukungan orangtua, kondisi sekolah, kurangnya bimbingan karir yang tersedia, kurangnya minat terhadap mata pelajaran tertentu, dan peran teman sebaya (Kesuma, Sugiharto \& Sunawan, 2018).

Menurut Sukardi (1994) minat merupakan salah satu unsur kepribadian yang memegang peran penting dalam mengambil keputusan di masa depan. Minat sangat penting bagi remaja karena minat memainkan peran dalam proses pembelajaran dan prestasi akademik, artinya remaja memiliki ketertarikan pada suatu hal yang dapat meningkatkan pembelajaran, mengarah pada kinerja yang positif, serta prestasi yang baik (Harackiewicz \& Hulleman, 2010).
Berdasarkan studi pendahuluan yang telah dilakukan peneliti pada Februari 2019 kepada lima orang siswa perempuan SMA Negeri yang berada di Kabupaten Tabanan diperoleh hasil yaitu responden memiliki minat yang baik untuk melanjutkan studi ke perguruan tinggi. Hal tersebut sejalan dengan penelitian Severiens dan Dam (2010) yang menemukan bahwa siswa perempuan memiliki minat untuk melanjutkan pendidikan ke jenjang perguruan tinggi yang lebih tinggi dibandingkan dengan siswa laki-laki, hal tersebut dikarenakan siswa perempuan menganggap bahwa pendidikan sangatlah penting untuk mempersiapkan mereka memasuki dunia kerja. Terdapat salah satu prediktor penting yang mempengaruhi minat siswa untuk melanjutkan studi ke perguruan tinggi yaitu motivasi berprestasi (Arendra, 2016). Motivasi berprestasi, keterampilan, serta kedisiplinan yang dimiliki siswa perempuan lebih baik dibandingkan dengan siswa laki-laki (Severiens \& Dam, 2010). Hal tersebut dibuktikan dengan prestasi yang telah diraih para siswa, baik dalam bidang akademik maupun non akademik, seperti mendapatkan juara dalam perlombaan karate, cerdas cermat, menggambar, serta mendapatkan ranking 10 besar di kelas bahkan ada yang 
mendapatkan juara umum di sekolah (Nadi, 2020). Ranking kelas atau prestasi yang didapat menunjukkan bahwa individu telah mengembangkan motivasi berprestasi dengan baik (Rubiyanto, Hartini, \& Mulyadi, 2012).

Namun adanya motivasi berprestasi yang baik berbanding terbalik dengan status sosial ekonomi yang dimiliki orangtua responden. Akibat rendahnya status sosial ekonomi tersebut akhirnya membuat responden berencana mengurungkan niatnya untuk melanjutkan studi ke perguruan tinggi dan orangtua juga menyarankan para responden mencari beasiswa untuk mengurangi pengeluaran terutama yang berkaitan dengan hal pendidikan. Maka dari itu, dua dari lima responden berencana untuk menunda kuliahnya terlebih dahulu dan fokus bekerja dengan tujuan untuk membantu melunasi hutang orangtua, serta mengumpulkan biaya yang nantinya digunakan untuk melanjutkan studi di perguruan tinggi (Nadi, 2020). Sejalan dengan penelitian Rahmawati \& Hakim (2015) ditemukan bahwa orangtua yang memiliki penghasilan rendah, akan membuat remaja bekerja membantu orangtua untuk mencari nafkah, sehingga remaja cenderung mengurungkan minatnya untuk melanjutkan studi ke perguruan tinggi.

Selain rendahnya status sosial ekonomi yang dimiliki masing-masing responden, terdapat pula alasan orangtua tidak memberikan izin kepada para responden untuk melanjutkan studi ke perguruan tinggi yaitu orangtua ingin anak mereka tinggal dan membantu pekerjaan rumah, dan orangtua menganggap bahwa anak perempuan tidak perlu mengenyam pendidikan sampai ke perguruan tinggi (Nadi, 2020). Sejalan dengan penelitian Roziqin, Suwitri, Apryanto \& Sihidi (2019) yang menemukan bahwa dalam memperoleh akses pendidikan siswa perempuan lebih dibatasi dibandingkan dengan siswa laki-laki, hal tersebut dikarenakan semakin tinggi jenjang pendidikan dimiliki, maka semakin lebar kesenjangan antara laki-laki dan perempuan. Kesenjangan ini nantinya akan berdampak pada perbedaan penghasilan antara laki-laki dan perempuan.

Meskipun status sosial ekonomi yang dimiliki rendah dan orangtua tidak mengizinkan responden untuk melanjutkan studi ke perguruan tinggi, para responden tetap bertekad untuk melanjutkan studi ke perguruan tinggi. Hal tersebut dibuktikan responden dengan 
melakukan berbagai macam upaya seperti mencari informasi tentang beasiswa perkuliahan, dan melakukan part time di sela-sela kegiatan sekolahnya. Sejalan dengan penelitian Herdianti (2016) yang menemukan bahwa status sosial ekonomi orangtua tidak berpengaruh terhadap minat siswa dalam melanjutkan studi ke perguruan tinggi, sehingga siswa dengan status sosial ekonomi yang rendah dan memiliki minat yang tinggi dapat melanjutkan studi ke perguruan tinggi yang diinginkan.

Terdapat beberapa faktor yang mempengaruhi minat yaitu faktor internal dan faktor eksternal. Faktor internal meliputi genetik, kepribadian, mendalami ilmu pengetahuan, menginginkan perubahan, dan motivasi berprestasi (Rahmat, 2018). Faktor lainnya yang mempengaruhi minat yaitu faktor eksternal yang terdiri dari lingkungan keluarga seperti pendapatan orangtua, pekerjaan, pendidikan, lingkungan masyarakat, dan lingkungan sosial (Indriani, 2018).

Motivasi berprestasi merupakan salah satu faktor internal yang mempengaruhi minat. Menurut $\mathrm{Mc}$ Cleland (1978) motivasi berprestasi merupakan sebuah dorongan untuk mengerjakan tugas dengan baik dan biasanya terdapat standar keunggulan yang ditetapkan. Salah satu faktor eksternal yang mempengaruhi minat adalah pendapatan orangtua. Pendapatan orangtua merupakan salah satu prediktor penting dalam menentukan status sosial ekonomi individu (Chotimah, Ani \& Widodo, 2017). Status sosial ekonomi merupakan suatu kedudukan yang diatur secara sosial dan menempatkan seseorang pada posisi tertentu di dalam struktur sosial masyarakat (Adi, 2004). Kondisi sosial ekonomi orangtua sangat penting karena status sosial ekonomi dapat menunjang dan memenuhi semua kebutuhan remaja termasuk dalam meningkatkan minat remaja untuk melanjutkan studi ke perguruan tinggi yang diminati (Zaini, Sujito \& Andayani, 2015). Namun terdapat temuan yang berbeda dari penelitian Herdianti (2016) yaitu status sosial ekonomi orangtua tidak berpengaruh terhadap minat siswa dalam melanjutkan studi ke perguruan tinggi, sehingga siswa dengan status sosial ekonomi yang rendah dan memiliki minat yang tinggi dapat melanjutkan studi ke perguruan tinggi yang diinginkan.

TINJAUAN PUSTAKA

Minat melanjutkan studi ke perguruan tinggi 
Notodiharjo (1990) mendefinisikan minat melanjutkan studi ke perguruan tinggi sebagai rasa tertarik terhadap salah satu jenis perguruan tinggi, disertai dengan usaha untuk mencapainya. Minat melanjutkan perguruan tinggi menggiring individu untuk menentukan pilihan pendidikan tinggi yang nantinya akan dipilih. Minat melanjutkan perguruan tinggi juga dapat didefinisikan sebagai ketertarikan siswa untuk melanjutkan studi ke perguruan tinggi yang tumbuh secara sadar di dalam diri. Ketertarikan tersebut menyebabkan siswa memberikan perhatian yang lebih terhadap perguruan tinggi yang akan mereka pilih (Syah,2004). Ginting mengemukakan bahwa terdapat beberapa faktor yang mempengaruhi minat melanjutkan studi ke perguruan tinggi antara lain, faktor internal dan faktor eksternal. Faktor internal merupakan faktor yang berasal dari dalam diri individu seperti bakat, kecerdasan, kreativitas, motivasi, minat dan perhatian, serta kondisi jasmaniah atau mental. Faktor eksternal merupakan faktor yang berasal dari luar diri individu seperti lingkungan sosial, lingkungan fisik, dan fasilitas belajar.

\section{Motivasi Berprestasi}

Mc Clelland (1978) mendefinisikan motivasi berprestasi sebagai suatu kemampuan yang dimiliki individu untuk mencapai standar atau target kepandaian, dan keahlian yang telah ditentukan. Heckhausen (1967) juga mengemukakan bahwa motivasi berprestasi merupakan suatu dorongan yang terdapat dalam diri individu untuk selalu berusaha atau berjuang dalam meningkatkan atau memelihara kemampuannya setinggi mungkin di semua aktivitas dengan menggunakan standar keunggulan. Mc Clelland (1978) mengemukakan bahwa terdapat beberapa aspek yang mempengaruhi motivasi berprestasi antara lain tanggung jawab, mempertimbangkan risiko dalam pengambilan tugas, memperhatikan umpan balik yang diterima, kratif dan inovatif, waktu penyelesaian tugas, serta keinginan menjadi yang terbaik.

\section{Status Sosial Ekonomi}

Adi (2004) mendefinisikan status sosial ekonomi sebagai suatu kedudukan yang dapat diatur secara sosial dan menempatkan seseorang pada posisi tertentu di dalam struktur sosial masyarakat. Status sosial ekonomi juga dapat didefinisikan sebagai suatu kedudukan yang dapat diatur secara sosial pada individu dan kedudukan tersebut 
dapat dilihat dari tingkat pendidikan, pekerjaan, serta pendapatan dari orangtua (Sugihartono, 2007). Talcott (1951) mengemukakan bahwa terdapat beberapa aspek yang memiliki peran dalam menentukan status sosial ekonomi individu yaitu pendapatan, pekerjaan, luas rumah, wilayah tempat tinggal, dan pendidikan.

\section{METODE PENELITIAN}

\section{Subjek Penelitian}

Populasi yang digunakan dalam penelitian ini adalah Siswa Perempuan yang ada di 11 SMA Negeri di Kabupaten Tabanan dengan usia 17-18 tahun. Teknik pengambilan sampel menggunakan cluster sampling dengan merandomisasi 11 sekolah dari 10 kecamatan yang ada di Kabupaten Tabanan. Sampel dalam penelitian ini memiliki karakteristik sebagai berikut: Siswa perempuan yang sedang mengenyam pendidikan di Sekolah Menengah Atas (SMA Negeri) di Tabanan dan Berada pada rentang usia 17-18 tahun.

\section{Tempat Penelitian}

Penelitian dilaksanakan pada bulan Juli 2020 di beberapa SMA Negeri di Kabupaten Tabanan. Subjek penelitian yang digunakan telah melalui proses randomisasi sehingga subjek dalam penelitian ini merupakan Siswa perempuan yang berada di SMAN 1
Kediri dan SMAN 1 Margarana. Teknik pengumpulan data menggunakan skala motivasi berprestasi dan skala minat melanjutkan studi ke perguruan tinggi, serta angket status sosial ekonomi yang disebarkan melalui google form. Jumlah keseluruhan kuesioner yang didapat sebanyak 153 buah, namun hanya 127 kuesioner yang memenuhi prasyarat uji sehingga subjek pada penelitian ini sebanyak 127 orang.

\section{Alat Ukur}

Alat ukur dalam penelitian ini menggunakan skala likert yaitu skala motivasi berprestasi dan minat melanjutkan studi ke perguruan tinggi serta angket tertutup yaitu angket status sosial ekonomi. Jumlah aitem skala motivasi berprestasi yaitu 40 aitem dengan koefisien reliabilitas alpha sebesar 0,905, angket status sosial ekonomi berjumlah 8 aitem dengan koefisien reliabilitas alpha sebesar 0,668 , dan skala minat melanjutkan studi ke perguruan tinggi berjumlah 26 aitem dengan koefisien reliabilitas alpha sebesar 0,857 .

\section{HASIL DAN PEMBAHASAN}

\section{Hasil Penelitian}

Berdasarkan hasil perhitungan batas atas (skor maksimum) dan batas bawah (skor minimum), hasil tersebut dimasukkan kedalam lima kategori yaitu 
sangat tinggi, tinggi, sedang, rendah, dan sangat rendah.

Tabel 1. Kategorisasi Motivasi Berprestasi.

\begin{tabular}{|l|l|l|l|}
\hline $\begin{array}{l}\text { Rentang } \\
\text { Nilai }\end{array}$ & Kategori & Jumlah & $\begin{array}{l}\text { Prese } \\
\text { ntase }\end{array}$ \\
\hline $\mathrm{X} \leq 70$ & $\begin{array}{l}\text { Sangat } \\
\text { Rendah }\end{array}$ & 13 & $8,6 \%$ \\
\hline $70<\mathrm{X} \leq 90$ & Rendah & 51 & $39,4 \%$ \\
\hline $90<\mathrm{X} \leq 110$ & Sedang & 40 & $29,9 \%$ \\
\hline $110<\mathrm{X} \leq 130$ & Tinggi & 22 & $16,5 \%$ \\
\hline $130<\mathrm{X}$ & $\begin{array}{l}\text { Sangat } \\
\text { Tinggi }\end{array}$ & 1 & $5,6 \%$ \\
\hline & Total & 127 & $100 \%$ \\
\hline
\end{tabular}

Berdasarkan hasil kategorisasi pada

tabel 1 bahwa variabel motivasi berprestasi dapat dijelaskan bahwa subjek dalam penelitian ini memiliki taraf motivasi berprestasi yang cenderung rendah.

Tabel 2. Kategorisasi Status Sosial Ekonomi.

\begin{tabular}{|l|l|l|l|}
\hline $\begin{array}{l}\text { Rentang } \\
\text { Nilai }\end{array}$ & Kategori & Jumlah & $\begin{array}{l}\text { Prese } \\
\text { ntase }\end{array}$ \\
\hline $\mathrm{X} \leq 14$ & $\begin{array}{l}\text { Sangat } \\
\text { Rendah }\end{array}$ & 1 & $0,8 \%$ \\
\hline $14<\mathrm{X} \leq 18$ & Rendah & 16 & $\begin{array}{l}10,3 \\
\%\end{array}$ \\
\hline $18<\mathrm{X} \leq 22$ & Sedang & 40 & $\begin{array}{l}27,6 \\
\%\end{array}$ \\
\hline $22<\mathrm{X} \leq 26$ & Tinggi & 44 & $\begin{array}{l}34,6 \\
\%\end{array}$ \\
\hline $26<\mathrm{X}$ & $\begin{array}{l}\text { Sangat } \\
\text { Tinggi }\end{array}$ & 26 & $\begin{array}{l}26,7 \\
\%\end{array}$ \\
\hline & Total & 127 & $100 \%$ \\
\hline
\end{tabular}

Berdasarkan hasil kategorisasi pada

tabel 2 bahwa variabel status sosial ekonomi dapat dijelaskan bahwa subjek dalam penelitian ini memiliki taraf status sosial ekonomi cenderung tinggi.

Tabel 3. Kategorisasi Minat Melanjutkan Studi ke Perguruan Tinggi.

\begin{tabular}{|l|l|l|l|}
\hline Rentang Nilai & Kategori & $\begin{array}{l}\text { Juml } \\
\text { ah }\end{array}$ & $\begin{array}{l}\text { Present } \\
\text { ase }\end{array}$ \\
\hline $\mathrm{X} \leq 45,5$ & $\begin{array}{l}\text { Sangat } \\
\text { Rendah }\end{array}$ & 23 & $17,3 \%$ \\
\hline $45,5<\mathrm{X} \leq 58,5$ & Rendah & 55 & $39,4 \%$ \\
\hline
\end{tabular}

\begin{tabular}{|l|l|l|l|}
\hline $58,5<\mathrm{X} \leq 71,5$ & Sedang & 25 & $18,9 \%$ \\
\hline $71,5<\mathrm{X} \leq 84,5$ & Tinggi & 16 & $12,7 \%$ \\
\hline $84,5<\mathrm{X}$ & $\begin{array}{l}\text { Sangat } \\
\text { Tinggi }\end{array}$ & 8 & $11,7 \%$ \\
\hline & Total & 127 & $100 \%$ \\
\hline
\end{tabular}

Berdasarkan hasil kategorisasi pada tabel 3 bahwa variabel minat melanjutkan studi ke perguruan tinggi dapat dijelaskan bahwa subjek dalam penelitian ini memiliki taraf minat melanjutkan studi ke perguruan tinggi cenderung rendah.

\section{Uji Asumsi Penelitian}

Teknik analisis data yang digunakan dalam penelitian ini adalah Uji regresi berganda. Sebelum melakukan analisis, peneliti telah melakukan uji asumsi berupa uji normalitas, linearitas, dan uji multikolinearitas.

\section{Uji Normalitas}

Uji normalitas bertujuan untuk menguji tingkat kenormalan distribusi sebaran skor variabel bebas yaitu motivasi berprestasi serta variabel terikat yaitu minat dengan menggunakan Kolmogorov Smirnof. Apabila nilai signifikansi lebih besar dari 0,05 maka data berdistribusi normal, dan apabila nilai signifikansi kurang dari 0,05 maka data berdistribusi tidak normal.

Tabel 4. Hasil Uji Normalitas.

\begin{tabular}{|l|l|l|l|}
\hline Variabel & $\begin{array}{l}\text { Kolmogoro } \\
\text { f-Smirnov }\end{array}$ & Sig. & $\begin{array}{l}\text { Kesimpu } \\
\text { lan }\end{array}$ \\
\hline $\begin{array}{l}\text { Motivasi } \\
\text { Berprestasi }\end{array}$ & 0,861 & 0,449 & $\begin{array}{l}\text { Data } \\
\text { Normal }\end{array}$ \\
\hline $\begin{array}{l}\text { Minat } \\
\text { Melanjutka } \\
\text { n Studi ke } \\
\text { Perguruan }\end{array}$ & 1,300 & 0,068 & $\begin{array}{l}\text { Data } \\
\text { Normal }\end{array}$ \\
\hline
\end{tabular}




\begin{tabular}{|l|l|l|l|}
\hline Tinggi & & & \\
\hline Status & 0,787 & 0,565 & Data \\
Sosial & & & Normal \\
Ekonomi & & & \\
\hline
\end{tabular}

Berdasarkan hasil uji normalitas

pada tabel 4, dapat disimpulkan bahwa ketiga variabel berdistribusi normal.

\section{Uji Linearitas}

Uji linearitas digunakan untuk melihat spesifikasi model yang digunakan sudah benar atau tidak. Dalam pengambilan keputusan didasarkan pada nilai signifikansi pada linearity lebih kecil dari $0,05(\mathrm{p}<0,05)$ ata nilai deviation of linearitynya lebih besar dari 0,05 ( $\mathrm{p}>0,05)$ maka hubungan antara dua variabel dinyatakan linier.

Tabel 5. Uji Linearitas.

\begin{tabular}{|l|l|l|l|}
\hline Variabel & $\begin{array}{l}\text { Linear } \\
\text { ity }\end{array}$ & $\begin{array}{l}\text { Deviation } \\
\text { from } \\
\text { Linearity }\end{array}$ & $\begin{array}{l}\text { Kesimp } \\
\text { ulan }\end{array}$ \\
\hline $\begin{array}{l}\text { Motivasi } \\
\text { berprestasi* } \\
\text { Minat } \\
\text { Melanjutkan } \\
\text { Studi ke } \\
\text { Perguruan } \\
\text { Tinggi }\end{array}$ & 0,000 & 0,599 & $\begin{array}{l}\text { Data } \\
\text { Linear }\end{array}$ \\
\hline $\begin{array}{l}\text { Status sosial } \\
\text { ekonomi* } \\
\text { Minat } \\
\text { melanjutkan } \\
\text { studi ke } \\
\text { perguruan } \\
\text { tinggi }\end{array}$ & 0,094 & 0,356 & $\begin{array}{l}\text { Data } \\
\text { Linear }\end{array}$ \\
\hline \multicolumn{2}{|c|}{ Berdasarkan hasil uji linearitas } \\
\hline
\end{tabular}

pada tabel 5, dapat disimpulkan bahwa terdapat hubungan yang linear antara variabel motivasi berprestasi dan minat melanjutkan studi ke perguruan tinggi serta status sosial ekonomi dan minat melanjutkan studi ke perguruan tinggi.

\section{Uji Multikolinearitas}

Uji multikolinearitas bertujuan untuk menguji apakah model regresi yang ditemukan memiliki korelasi antara variabel bebas. Untuk mendeteksi adanya multikolinearitas di dalam regresi, maka dapat dilihat dari nilai toleransi kurang dari 0,10 atau sama dengan nilai VIF lebih besar dari 0,10. Jika nilai toleransi kurang dari 0,10, maka tidak ada multikolinearitas antar variabel independen dalam model regresi.

Tabel 6. Hasil Uji Multikolinearitas.

\begin{tabular}{|l|l|l|l|}
\hline Variabel & Tolerance & VIF & Kesimpulan \\
\hline $\begin{array}{l}\text { Motivasi } \\
\text { berprestasi }\end{array}$ & 0,973 & $\begin{array}{l}1,02 \\
8\end{array}$ & $\begin{array}{l}\text { Tidak terjadi } \\
\text { multikolineari } \\
\text { tas }\end{array}$ \\
\hline $\begin{array}{l}\text { Status } \\
\begin{array}{l}\text { Sosial } \\
\text { Ekonomi }\end{array}\end{array}$ & 0,973 & $\begin{array}{l}1,02 \\
8\end{array}$ & $\begin{array}{l}\text { Tidak terjadi } \\
\text { multikolineari } \\
\text { tas }\end{array}$ \\
\hline
\end{tabular}

Berdasarkan

hasil

uji

multikolinearitas pada tabel 6, dapat disimpulkan bahwa variabel motivasi berprestasi dan status sosial ekonomi tidak terjadi multikolinearitas.

\section{Uji Hipotesis}

Uji hipotesis dalam penelitian ini yaitu uji regresi berganda. Uji Regresi berganda digunakan untuk mengetahui kekuatan prediksi dari beberapa variabel independen terhadap variabel independen (Silalahi, 2017). Dasar pengambilan keputusan uji regresi berganda yaitu nilai signifikansi $5 \%$ atau 0,05 . Apabila nilai signifikansi lebih kecil dari 0,05 ( $<<0,05)$, maka $\mathrm{H}_{\mathrm{a}}$ diterima dan $\mathrm{H}_{0}$ ditolak yang 
berarti variabel bebas berperan secara signifikan terhadap variabel tergantung.

Tabel 7. Hasil Uji Regresi Berganda.

\begin{tabular}{|c|c|c|c|c|c|}
\hline & $\begin{array}{l}\text { Sum of } \\
\text { Square }\end{array}$ & Df & $\begin{array}{l}\text { Mean } \\
\text { Square }\end{array}$ & $\mathbf{F}$ & Sig \\
\hline $\begin{array}{l}\text { Regre } \\
\text { ssion }\end{array}$ & $\begin{array}{l}11996,8 \\
00\end{array}$ & 2 & $\begin{array}{l}5998,4 \\
00\end{array}$ & $\begin{array}{l}37, \\
192 \\
\end{array}$ & $\begin{array}{l}0,0 \\
00 \\
\end{array}$ \\
\hline $\begin{array}{l}\text { Resid } \\
\text { ual }\end{array}$ & $\begin{array}{l}19999,0 \\
59\end{array}$ & 124 & $\begin{array}{l}161,28 \\
3\end{array}$ & & \\
\hline Total & $\begin{array}{l}31995,8 \\
58\end{array}$ & 126 & & & \\
\hline
\end{tabular}

Berdasarkan hasil uji regresi

berganda pada tabel 7 , menunjukkan $\mathrm{F}$ hitung sebesar 37,192 dengan tingkat signifikansi sebesar $0,000(\mathrm{p}<0,05)$. Hal tersebut menunjukkan bahwa model regresi dapat digunakan untuk memprediksi minat melanjutkan studi ke perguruan tinggi atau dapat dikatakan bahwa motivasi berprestasi dan status sosial ekonomi secara bersama-sama dapat berperan terhadap minat melanjutkan studi ke perguruan tinggi.

\section{Pembahasan Penelitian}

Berdasarkan hasil analisis uji regresi berganda yang telah dilakukan sebelumnya, variabel motivasi berprestasi dan minat melanjutkan studi ke perguruan tinggi memiliki nilai koefisien beta terstandarisasi sebesar 0,577 dengan taraf signifikansi sebesar 0,000 p-value $<0,05$. Hal ini menunjukkan bahwa motivasi berprestasi berperan secara signifikan terhadap minat melanjutkan studi ke perguruan tinggi dengan arah yang positif. Artinya semakin tinggi motivasi berprestasi, maka semakin tinggi pula minat melanjutkan studi ke perguruan tinggi. Dapat dikatakan juga bahwa motivasi berprestasi berperan secara signifikan dalam meningkatkan minat melanjutkan studi ke perguruan tinggi. Hal ini sejalan dengan penelitian Djaali (2012) yang menemukan bahwa motivasi berprestasi akan mempengaruhi segala hal untuk mencapai setiap keinginan siswa, bukan hanya sekedar dorongan untuk berbuat tetapi mengacu pada suatu ukuran keberhasilan penilaian terhadap tugas yang dikerjakan seseorang. Adanya motivasi berprestasi yang baik akan mendorong individu untuk mencapai kesuksesan dan menghindari kegagalan dalam mendapatkan hasil belajar yang baik. Hasil belajar yang baik akan membuat individu percaya diri dalam menetapkan cita-cita memilih perguruan tinggi yang diinginkan (Sujarwo, 2011).

Berdasarkan hasil uji regresi berganda yang dilakukan pada penelitian ini, variabel status sosial ekonomi dan minat melanjutkan studi ke perguruan tinggi memiliki nilai koefisien beta terstandarisasi sebesar -0,208 dengan taraf signifikansi sebesar 0,493 p-value $>0,05$. Hal ini menunjukkan bahwa status sosial ekonomi berperan secara tidak signifikan terhadap minat melanjutkan studi ke 
perguruan tinggi dengan arah yang negatif. Artinya semakin rendah status sosial ekonomi, maka semakin tinggi pula minat melanjutkan studi ke perguruan tinggi. Dapat dikatakan juga bahwa status sosial ekonomi tidak berperan secara signifikan dalam meningkatkan minat melanjutkan studi ke perguruan tinggi. Hasil penelitian ini menunjukkan mayoritas subjek memiliki tingkat status sosial ekonomi sangat tinggi. Sangat tingginya status sosial ekonomi yang dimiliki subjek tidak mempengaruhi tingginya minat melanjutkan studi ke perguruan tinggi yang dimiliki subjek.

Sejalan dengan hasil penelitian Herdianti (2016) yang menemukan bahwa status sosial ekonomi orangtua tidak berpengaruh terhadap minat siswa dalam melanjutkan studi ke perguruan tinggi, sehingga siswa dengan status sosial ekonomi yang rendah dan memiliki minat yang tinggi dapat melanjutkan studi ke perguruan tinggi yang diinginkan. Darmawan (2016) juga menemukan bahwa status sosial ekonomi tidak memiliki hubungan yang signifikan dengan minat melanjutkan studi ke perguruan tinggi. Hal tersebut ditunjukkan dengan siswa dengan kategori status sosial ekonomi rendah, siswa dengan status sosial ekonomi sedang, dan siswa dengan status sosial ekonomi tinggi sama-sama memiliki minat untuk melanjutkan studi ke perguruan tinggi dengan taraf yang tinggi.

\section{PENUTUP}

\section{Kesimpulan}

Berdasarkan hasil penelitian yang telah dilakukan maka didapatkan kesimpulan, terdapat peran motivasi berprestasi dan status sosial ekonomi berperan terhadap minat melanjutkan studi ke perguruan tinggi pada siswa perempuan di Tabanan, motivasi berprestasi berperan terhadap minat melanjutkan studi ke perguruan tinggi pada siswa perempuan di Tabanan, status sosial ekonomi tidak berperan terhadap minat melanjutkan studi ke perguruan tinggi pada siswa perempuan di Tabanan, motivasi berprestasi pada siswa perempuan di Tabanan berada pada kategori rendah, minat melanjutkan studi ke perguruan tinggi pada siswa perempuan di Tabanan berada pada kategori rendah, dan status sosial ekonomi orangtua pada siswa perempuan di Tabanan berada pada kategori tinggi.

\section{Saran}

Berdasarkan kesimpulan yang diperoleh maka dapat disampaikan beberapa saran praktis yaitu:

Bagi Siswa SMA 
Para siswa diharapkan dapat meningkatkan dan mempertahankan motivasi berprestasi serta minat dalam melanjutkan studi ke perguruan tinggi.

Bagi Orangtua

Pihak orangtua hendaknya membantu siswa untuk meningkatkan motivasi berprestasi sejak dini agar nantinya siswa memiliki minat melanjutkan ke perguruan tinggi yang baik.

Bagi Pihak Sekolah

$$
\text { Pihak sekolah hendaknya }
$$
memberikan informasi terkait dengan perguruan tinggi, beasiswa, dan pemberian bimbingan terkait dengan persiapan siswa dalam melanjutkan studi ke perguruan tinggi, sehingga siswa dapat mengetahui ruang lingkup perguruan tinggi dan meningkatkan minat mereka dalam melanjutkan studi ke perguruan tinggi.

Bagi Peneliti Selanjutnya

Peneliti selanjutnya yang ingin melakukan penelitian serupa, diharapkan dapat menambah sampel penelitian. Hal tersebut dilakukan agar data yang diperoleh lebih representatif. Peneliti selanjutnya diharapkan dapat meneliti variabel lain yang tidak diteliti pada penelitian ini yang mungkin dapat mempengaruhi minat siswa dalam melanjutkan studi ke perguruan tinggi.

\section{DAFTAR PUSTAKA}

Arse, E. D. 2014. Pengaruh Hasil Belajar, Motivasi Berprestasi, Status Sosial Ekonomi Keluarga Terhadap Minat Melanjutkan Ke Perguruan Tinggi (Studi Pada Siswa Siswa Kelas Xi Jurusan Pemasaran Smk Negeri Pasirian Tahun Ajaran 2013/2014. (Skripsi). Universitas Negeri Malang.

Azwar, S. 2016. Metode Penelitian. Yogyakarta: Pustaka Pelajar.

Azwar, S. 2016. Reliabilitas dan Validitas. Yogyakarta: Pustaka Pelajar.

Djali. 2017. Psikologi Pendidikan. (Cetakan Kesepuluh). Jakarta: Bumi Aksara.

Emelia, E. 2014. Pengaruh Status Sosial Ekonomi Orangtua Terhadap Minat Melanjutkan Studi Ke Perguruan Tinggi Pada Siswa Kelas Xii Smkn 1 Padang. (Skripsi). Padang: STKI PGRI Sumatera Barat

Field, A. 2009. Discovering Statistics Using Spss. (Third Edition). Singapore: SAGE Publications.

Feisal, J. A. 1995. Reorientasi Pendidikan Islam. (Cetakan Pertama). Jakarta: Gema Isani Press.

Forgas, J.P., Williams, K.D., \& Simon, L.M. 2004. Social Motivation: Conscious and Unconscious Processes. United States of America: Cambridge University Press.

Ghozali, I. 2018. Aplikasi Analisis Multivariate Dengan Program Spss. $3^{\text {rd }}$ Edition: SAGE Publication.

Ginting, C. 2003. Kiat Belajar Di Perguruan Tinggi. Jakarta: Garasindo.

Hurlock, E. B. 1996. Personality Development. (Edisi Kelima). Jakarta: Penerbit Erlangga. 
Hurlock, E. B. 2009. Psikologi Perkembangan: Suatu Perkembangan Sepanjang Rentan Kehidupan. Jakarta: Penerbit Erlangga.

Hurlock, E. B. 2011. Psikologi Perkembangan: Suatu Perkembangan Sepanjang Rentan Kehidupan. Jakarta: Penerbit Erlangga.

Indriani, M. 2018. Pengaruh Hasil Belajar, Motivasi Berprestasi, Dan Pendapatan Orang Tua Terhadap Minat Melanjutkan Pendidikan Ke Perguruan Tinggi Pada Siswa Kelas $\mathrm{Xi}$ Ips Sma Negeri 1 Pejagoan Kebumen Tahun Ajaran 2017/2018.Jurnal pendidikan ekonomi. 7(5).

McClelland, D.C. 1976. The Achievement Motivate. New York: Irvingnon Publisher.

McClelland, D. C. 1978. Human Motivation. New York: The Press Syndicate of The University of Cambridge.

Nadi, N. P. D. M. 2020. Peran Motivasi Berprestasi Dan Status Sosial Ekonomi Terhadap Minat Melanjutkan Studi Ke Perguruan Tinggi Pada Siswa Perempuan Di Tabanan. (Skripsi). Universitas Udayana. 